\title{
Organization of morphological and genetic diversity of Caribbean and Venezuelan papaya germplasm
}

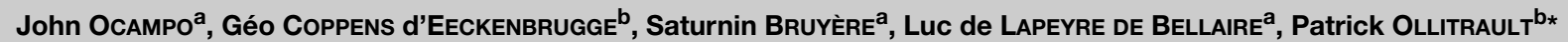

a Cirad, Station de Neufchâteau, Sainte-Marie, 97130 Capesterre-Belle-Eau, Guadeloupe, France

b Cirad, Boulevard de la Lironde, TS 50 / PS4, 34398 Montpellier Cedex 5, France patrick.ollitrault@cirad.fr

* Correspondence and reprints

Received 11 July 2005

Accepted 24 November 2005

Fruits, 2006, vol. 61, p. 25-37 (C) 2006 Cirad/EDP Sciences All rights reserved DOI: 10.1051/fruits:2006003

RESUMEN ESPAÑOL, p. 37

\section{Organization of morphological and genetic diversity of Caribbean and Venezuelan papaya germplasm.}

Abstract - Introduction. The severe impact of papaya bacterial canker in the West Indies justified launching a program to transfer the genetic resistance/tolerance identified in local germplasm to good-quality cultivars. As a first step, a germplasm collection from the Caribbean was gathered and its morphological and genetic diversity assessed. Materials and methods. The total sample included 50 accessions from the Lesser Antilles, Cuba, Venezuela, Costa Rica and Hawaii. Morphological data from a subsample of 29 accessions were submitted to analysis of variance, principal component analysis and Neighbor-Joining cluster analysis. Nine isozyme systems were tested, and the corresponding data were processed for cluster analysis and genetic parameters, including the fixation index, diversity indices and heterozygosity. Results. Eighteen of the 47 Caribbean and Venezuelan accessions exhibited hermaphroditism. Venezuelan accessions displayed the widest morphological diversity, while those from Barbados were distinguished by fruit quality. Sexual type affected leaf and flower traits. Cluster analysis shows little morphological differentiation between origins, with the relative grouping of the accessions from Guadeloupe or Barbados. Only four isozyme systems were polymorphic, producing 34 distinct zymotypes, with a relatively high heterozygosity and a particular diversity in Venezuela, Guadeloupe and Barbados. Geographic structuration appears limited in the cluster analysis among individuals; however, it is clearer when considering the six best-represented populations, with one cluster representing Venezuela, Trinidad and Barbados, and one for Guadeloupe, Martinique and Grenada. Discussion. The low level of fixation is attributed to dioecy and to the low level of selection. The relative isolation of island populations has favored geographic differentiation, albeit limited. The differentiation between the good-quality germplasm from Barbados and the tolerant populations from Martinique and Guadeloupe encourages the development of a marker-assisted introgression scheme.

Caribbean / Venezuela / Carica papaya / germplasm / isoenzymes

\section{Organisation de la diversité morphologique et génétique des papayers des Caraïbes et du Vénézuéla.}

Resumé - Introduction. Pour lutter contre le chancre bactérien qui empêche le développement du papayer aux Antilles, un programme visant à transférer les facteurs de résistance génétique de génotypes locaux vers des cultivars commerciaux a été mis sur pied. Dans une première étape, une collection de germplasm caribéen a été réunie pour en étudier la diversité morphologique et génétique. Matériels et méthodes. L'échantillon comprend 50 accessions des Petites Antilles, Cuba, Venezuela, Costa Rica et Hawaï. Les données morphologiques d'un sous-échantillon de 29 accessions ont été soumises à l' analyse de variance, l'analyse en composantes principales et la classification par la méthode du Neighbor Joining. Neuf systèmes enzymatiques ont été testés et les données correspondantes ont été traitées par analyses de classification et calcul des paramètres génétiques, notamment les indices de fixation, diversité et hétérozygotie. Résultats. Dixhuit des 47 accessions des Caraibes et du Vénézuéla ont présenté de l'hermaphrodisme. Les accessions du Venezuela ont montré la plus large diversité morphologique, tandis que celles de Barbade se sont distinguées par la qualité du fruit. Le type sexuel a influé sur les caractères foliaires et floraux. La classification montre peu de différenciation morphologique selon l'origine, avec les regroupements des accessions de Guadeloupe et de Barbade. Seuls quatre systèmes enzymatiques se sont révélés polymorphes, formant 34 zymotypes, avec une hétérozygotie relativement élevée et une diversité particulière au Venezuela, en Guadeloupe et à Barbade. La structuration géographique apparaît limitée dans l'analyse entre individus, mais elle est plus marquée si l'on considère les six populations les mieux représentées, avec un grand groupe pour le Venezuela, Trinidad et Barbade, et un autre pour la Guadeloupe, la Martinique et Grenade. Discussion. Le faible niveau de fixation peut être attribué à la dioécie et au faible niveau de sélection. La relative isolation des populations insulaires a favorisé une différenciation géographique limitée. La divergence entre le germplasm de bonne qualité de Barbade et les populations tolérantes de Martinique et Guadeloupe favorise le développement d'un schéma d'introgression assistée par marqueurs.

Caraïbes / Vénézuéla / Carica papaya / germplasm / isoenzyme 


\section{Introduction}

The production of papaya (Caricapapaya L.) is particularly attractive for fruit crop diversification in the West Indies because of its yield potential, rusticity, high demand on the local market and potential for export. However, the cultivation of papayas responding to modern export standards has been made impossible because of the extremely severe impact of a bacterial canker caused by Erwinia papayae [1-4]. This disease is present in most of the West Indies, from the Virgin Islands to Venezuela, with the exception of the Greater Antilles. Chemical control is not efficient [3] while genetic control is more promising, as some local populations have shown high levels of resistance/tolerance, particularly in Guadeloupe, Venezuela, Grenada and Trinidad $[1,5]$. The first selection operated on these materials suggests an interesting heritability of the resistance. However, their heterogeneity does not allow a uniform production and their pomological and organoleptic characteristics are not adapted to the sweet fruit market. A breeding program to create cultivars combining resistance to the bacteriosis with good fruit quality appears necessary to support fruit crop diversification in the French West Indies. The short-term objective is to supply the local green fruit market while the mediumterm objective is to develop production for the local and export sweet fruit markets.

The common papaya is the only species of the genus Carica (Caricaceae), which very probably originated in Mesoamerica. More precisely, the Caribbean coast of Central America appears to be the most probable center of origin of the crop [6]. Like most Caricaceae, the common papaya is a diploid (2 $n=18)$, dioecious species. However, many landraces and cultivars present hermaphrodite plants, which are generally preferred for production. They display considerable phenotypic variation for many morphological and horticultural traits. For example, Alvarez et al. [7] evaluated 22 accessions from the same Colombian landrace and reported a range of variation of $1-7 \mathrm{~kg}$ for fruit weight, 4-6 months for first flowering date, and 8.511 months to first harvest. Sánchez and Samaniego [8] reported similar variation among only four cultivars in Mexico. How- ever, there are few precise data on morphological diversity in papaya in the literature. Somsri [9] investigated the possibility of using morphological traits to predict sex type. He found plant height, plant height at first flower, leaf shape, shape of petiole sinus and number of nodes to first flower useful for cultivar identification. Plant height and number of nodes at first flower appeared useful for distinguishing between female, hermaphrodite and male hybrid plants, contradicting earlier results presented by Nakasone and Storey [10]. Three qualitative traits, stem color and pigmentation, and petiole color, were useful for identifying female and hermaphrodite plants seedlings in the Thai cultivar Khaeg Dum.

Tan and Weinheimer [11], in 1976, were the first to use isozyme markers for diversity studies in papaya, studying a sample of five cultivars from a Malaysian collection with five systems (PER, EST, LAP, ACP and AMY) and inferring possible relations between Malaysian strains and Hawaiian cultivars. In one of the cultivars, they observed bands that were present only in the hermaphrodite plants. In a similar study on a 10-cultivar sample from Thailand, Hawaii and Australia, Somsri [9] observed polymorphism in five isozyme systems (PGI, PGM, LAP, PER and EST) out of fifteen (the same plus IDH, ACP, $\mathrm{ADH}, \mathrm{AMY}, \mathrm{ACO}, \mathrm{SOD}, \mathrm{LDH}, \mathrm{MDH}, \mathrm{PGD}$ and GOT); in a second test involving 21 enzyme systems, PER, LAP and EST allowed one to distinguish male from female seedlings in the Australian cultivar Richter and PER and PGI allowed one to distinguish hermaphrodite from female seedlings in the Hawaiian cultivar Sunset. However, none of the 21 systems allowed one to distinguish between sexual types in F1 hybrids. Morshidi $[12,13]$ studied the banding patterns of nine systems (ACO, IDH, MDH, PGI, PGM, PGD, SKD, TPI and UGP), detecting 13 loci, nine of which (from seven systems) appeared polymorphic, and established Mendelian inheritance for eight loci. Analyzing a sample of 131 papaya accessions from Central and South America, Morshidi [13] observed polymorphism for six of these nine systems. With an interest in investigating wider crosses, Jobin-Decor et al. [14] studied the relationships between C.papaya and highland papayas (Vasconcellea spp.) 
with isozyme and RAPD markers. As the C. papaya sample constituted a bulk of 10 genotypes, no intraspecific variation was reported. Isozymes and RAPDs gave similar measures of genetic variation, indicating a clear separation between the two genera and underlining their potential in hybridization programs. Indeed, isozyme markers have been successfully used in papaya to assess the results of interspecific hybridization programs [15-18].

The Caribbean islands constitute a zone of secondary diversification, where populations present adaptation to local conditions. In addition, their archipelagic nature should favor a geographic structure of genetic diversity. The conservation and evaluation of the Caribbean germplasm is an important first step in the sustainable development of the crop. Thus, to establish the basis of the projected breeding program, a collection of germplasm from the West Indies and Venezuela was established and its morphological, pomological and genetic diversity was studied, the latter through isozyme diversity.

\section{Materials and methods}

\subsection{Materials}

The study was carried out in the Cirad-Flhor experimental station of Vieux-Habitants in Guadeloupe (French West Indies). The germplasm sample consisted of 86 individuals aged 9 months, representing 50 accessions from Guadeloupe (17), Venezuela (11), Barbados (4), Grenada (5), Hawaii (3), Martinique (2), Trinidad (2), Sainte Croix (2) and only one representative of Antigua, Saint Vincent, Costa Rica and Cuba (table I).

Bacterial disease affected the trial and killed some accessions before collecting data on fruit characteristics. Thus, morphological analysis was only done on 29 of these accessions (table I), while the 86 individuals were analyzed for isozenzymes.

\subsection{Morphological characterization}

The different sexual types observed were characterized for each accession, following a list of 45 morphological and pomological traits derived from a subset of the papaya descriptor list published by IPGRI [19]. Dimensions of floral parts were replaced by the total length and diameter of the flowers. The descriptors concerning leaf shape and seminal cavity were modified by reducing the number of categories (table II). Five measurements were taken for quantitative traits. For qualitative data, two female plants were characterized for each accession.

\subsection{Isozyme characterization}

Nine isozyme systems, superoxyde dismutase (SOD-EC 1.15.1.1.), phosphoglucose isomerase (PGI-EC 5.3.1.9.), phosphoglucomutase (PGM-EC 2.7.5.1), alcohol dehydrogenase (ADH-EC 1.1.1.1), esterase (EST-EC 3.1.1.1), malate dehydrogenase (MDH-EC 1.1.1.37), shikimate dehydrogenase (SkDH-EC 1.1.1.25), leucine aminopeptidase (LAP-EC 3.4.11) and isocitrate dehydrogenase (IDH-EC 1.1.1.42), were evaluated for each sexual type of all the accessions. The proteins were extracted by maceration, in a buffer solution $(25 \mathrm{~mL}$ of tris $\mathrm{HCl} 0.2 \mathrm{M} \mathrm{pH} 7.2,25 \mathrm{mg}$ cysteine-antioxydant and $150 \mu \mathrm{L}$ of Triton $\times 100$ diluted 10 times), and placed on a $12 \%$ starch gel at $4{ }^{\circ} \mathrm{C}$. Migration was carried out at a constant 4-50 mA intensity, under 130-170 V. Band revelation was classically based on the catalytic activity of the enzyme.

\subsection{Data analysis}

Quantitative data were submitted to analysis of variance to determine the influence of sex on morphology. Only the female plants were included in the subsequent analysis of structuration of the morphological diversity. Quantitative data were submitted to principal component analysis (PCA), with varimax rotation, using the Statistica package. Isozyme data were scored in binary format, with the presence or absence of each electromorph. Cluster analyses were carried out on the principal components with an eigenvalue close to or higher than 1.0, the qualitative data, and isozyme data, using the Neighbor-Joining method [20] or hierarchic ascendant analysis (HAC), using Euclidian average, Sokal and Michener, and Jaccard distances, respectively. Genetic diversity 
Table I.

Caribbean and Venezuelan papaya germplasm sample submitted $\left({ }^{*}\right)$ to morphological and isozyme characterization.

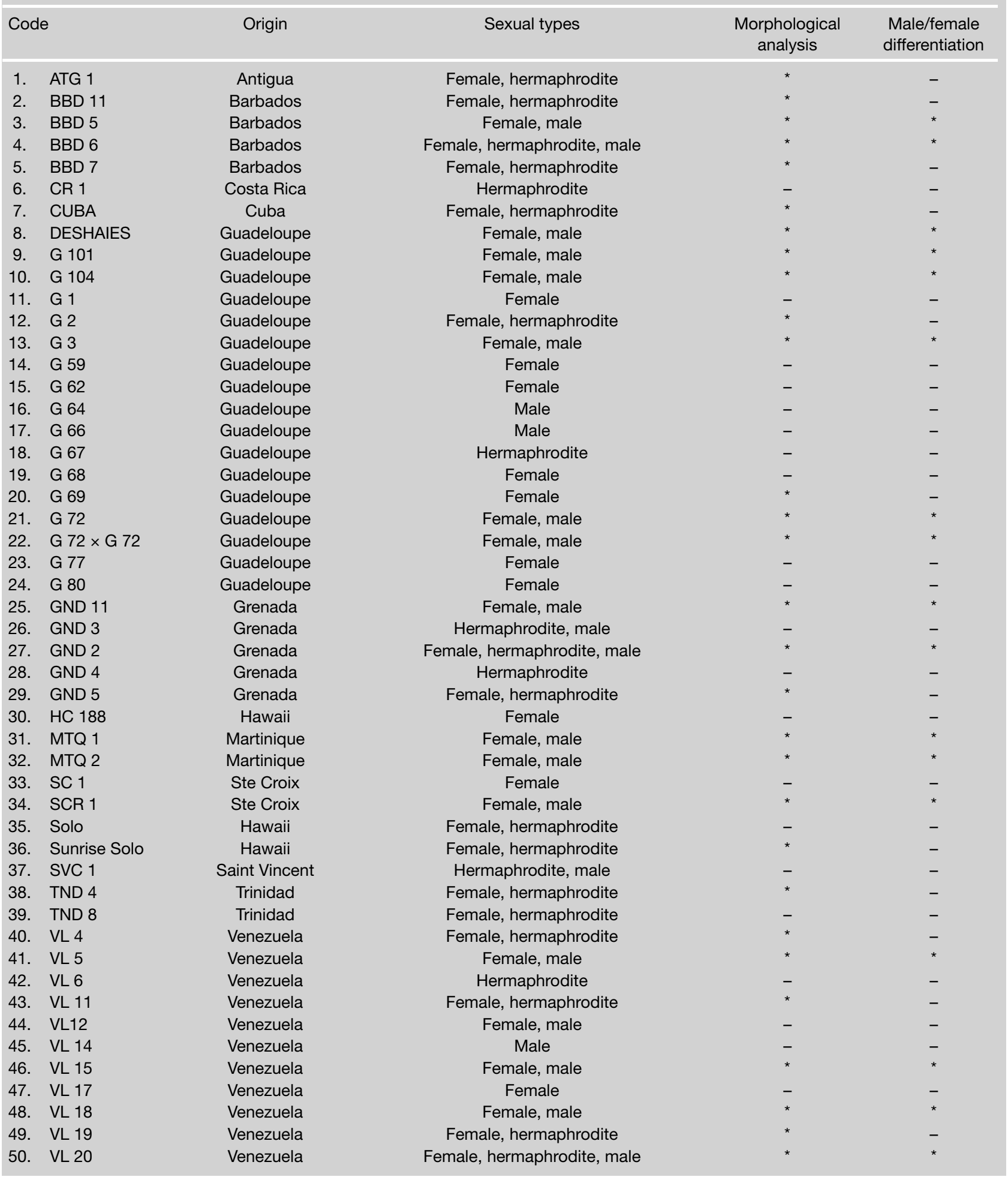


Table II.

Descriptor list used for morphological characterization of Caribbean and Venezuelan papaya germplasm samples.

\begin{tabular}{|c|c|c|}
\hline Organ & Quantitative traits & Qualitative traits \\
\hline Stem & $\begin{array}{l}\text { Height, nodes to flowering, } \\
\text { nodes to fruiting, } \\
\text { internode length, diameter, } \\
\text { height at first flower, } \\
\text { height at first fruit }\end{array}$ & Tree habit \\
\hline Petiole & Length & Color \\
\hline Leaf & Length, width & $\begin{array}{c}\text { General shape, shape of petiole sinus, } \\
\text { waxiness, pubescence }\end{array}$ \\
\hline Flower & Length & Color \\
\hline Inflorescence & $\begin{array}{l}\text { Inflorescence length, } \\
\text { [length/diameter] ratio, } \\
\text { flower number }\end{array}$ & Sexual type, type of hermaphroditism \\
\hline Fruit peduncle & Length & - \\
\hline Fruit & $\begin{array}{l}\text { Length, diameter, } \\
\text { size of blossom end scar, } \\
\text { weight, flesh density, } \\
\text { total soluble solids }\end{array}$ & $\begin{array}{l}\text { General shape, uniformity of fruit distribution, } \\
\text { shape at peduncle insertion, skin texture, } \\
\text { superficial depression, color at maturity, } \\
\text { shape of central cavity }\end{array}$ \\
\hline Seeds & Seed weight & Seed surface, mucilage quantity \\
\hline
\end{tabular}

parameters such as the fixation index [21], total, intra- and inter-population diversity [22] and heterozygosity were also analyzed for isozyme data.

\section{Results}

\subsection{Sexual type distribution}

The distribution of sexual types shows that only 21 accessions present hermaphroditism (table I). This trait is frequent in Bardados and Grenada, common in Venezuela ( 5 out of 11) and exceptional in the French West Indies.

\subsection{Morphological characterization}

Venezuelan accessions display an impressive variation in all aspects, including leaf shape and fruit size, shape and color. Thus VL 20 produces $0.12 \mathrm{~kg}$ fruits, while VL 19 produces huge, long fruits with a mean weight of $3.74 \mathrm{~kg}$. In the total sample, fruit variation was large (figure 1). The Barbados accessions present interesting fruits with good organoleptic characteristics, a reasonable fruit cavity, and a good shape, in relation to the frequency of hermaphrodite plants. However, they appear susceptible to bacteriosis. The accessions from Martinique also display fruits with good flavor but they are round and hollow, in relation to the prevalence of the female sexual type. In the whole sample, Total Soluble Solid content (TSS) varies from $4.60^{\circ}$ Brix in VL 4 to $13.3^{\circ}$ Brix in Sunrise Solo, with an average value of 7.64 .

The results of the analysis of variance carried out on the sample including data from

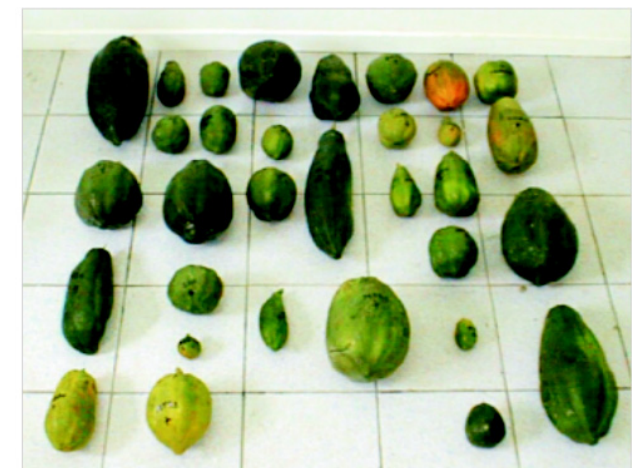

Figure 1.

Morphological diversity in the papaya germplasm from the Caribbean and Venezuela. 
Table III.

Analysis of variance comparing data from male and female Caribbean and Venezuelan papaya individuals. Five measurements were taken for each quantitative trait.

\begin{tabular}{|c|c|c|c|c|c|c|}
\hline Descriptors & Type sexual & Average & Standard error & Minimun & Maximun & $P$ value \\
\hline \multirow[t]{2}{*}{ Number of nodes to first flower } & Female & 31.5 & 1.730 & 11 & 58 & 0.0021 \\
\hline & Male & 39.6 & 2.290 & 21 & 59 & \\
\hline \multirow[t]{2}{*}{ Internode length } & Female & 2.2 & 0.188 & 0.7 & 5.3 & 0.6686 \\
\hline & Male & 2.7 & 0.273 & 1.1 & 5.8 & \\
\hline \multirow[t]{2}{*}{ Peduncle flower length } & Female & 4.8 & 0.410 & 2.7 & 10.6 & 0.0000 \\
\hline & Male & 73.5 & 5.710 & 22.8 & 124.1 & \\
\hline \multirow[t]{2}{*}{ [Length/diameter] flower ratio } & Female & 2.2 & 0.153 & 0.6 & 4.6 & 0.0000 \\
\hline & Male & 7.7 & 0.435 & 2.4 & 11 & \\
\hline \multirow[t]{2}{*}{ Plant height } & Female & 2.4 & 0.109 & 1.0 & 3.6 & 0.4697 \\
\hline & Male & 2.5 & 0.155 & 1.0 & 4.04 & \\
\hline \multirow[t]{2}{*}{ Stem diameter } & Female & 14.2 & 0.485 & 8.7 & 19.3 & 0.2022 \\
\hline & Male & 13.6 & 0.873 & 5.9 & 23.6 & \\
\hline \multirow[t]{2}{*}{ Height at first fruit } & Female & 36.2 & 7.297 & 1.0 & 98.6 & 0.0316 \\
\hline & Male & 8.2 & 4.609 & 1.1 & 69.3 & \\
\hline \multirow[t]{2}{*}{ Petiole length } & Female & 79.6 & 2.109 & 60.5 & 105.3 & 0.1133 \\
\hline & Male & 74.0 & 2.589 & 46.3 & 97.7 & \\
\hline \multirow[t]{2}{*}{ Leaf length } & Female & 71.7 & 1.946 & 50 & 92.1 & 0.0023 \\
\hline & Male & 65.4 & 1.719 & 53.2 & 80.6 & \\
\hline \multirow[t]{2}{*}{ Leaf width } & Female & 73.4 & 2.094 & 56 & 101.3 & 0.0298 \\
\hline & Male & 68.2 & 1.978 & 56.5 & 88 & \\
\hline
\end{tabular}

\section{Table IV.}

Correlation of principal components (rotation varimax normalized) with original quantitative variables observed on female Caribbean and Venezuelan papaya individuals.

\begin{tabular}{|c|c|c|c|c|c|c|c|}
\hline \multirow[t]{2}{*}{ Descriptors } & \multicolumn{7}{|c|}{ Principal components } \\
\hline & 1 & 2 & 3 & 4 & 5 & 6 & 7 \\
\hline Number of nodes to first flower & -0.302 & 0.441 & -0.057 & 0.076 & $-0.790^{*}$ & 0.115 & -0.049 \\
\hline Internode length & -0.025 & 0.227 & -0.133 & 0.422 & $0.774^{*}$ & 0.106 & 0.164 \\
\hline Peduncle flower length & 0.239 & 0.037 & 0.048 & 0.907 & 0.005 & 0.023 & -0.025 \\
\hline [Length/diameter] flower ratio & -0.103 & -0.049 & -0.148 & -0.354 & -0.124 & $-0.760^{*}$ & -0.236 \\
\hline Plant height & 0.025 & $0.833^{*}$ & -0.096 & 0.221 & 0.060 & 0.216 & -0.251 \\
\hline Stem diameter & 0.072 & $0.856^{*}$ & -0.069 & 0.057 & -0.005 & 0.028 & 0.062 \\
\hline Height at first fruit & -0.182 & $0.851^{*}$ & 0.161 & -0.158 & -0.125 & 0.026 & -0.152 \\
\hline Petiole length & -0.124 & 0.107 & $0.882^{*}$ & 0.017 & 0.068 & 0.104 & -0.213 \\
\hline Leaf length & 0.317 & -0.073 & $0.741^{*}$ & 0.235 & -0.177 & -0.350 & 0.257 \\
\hline Leaf width & 0.313 & -0.128 & $0.762^{*}$ & 0.077 & -0.053 & -0.071 & 0.425 \\
\hline Number of flowers per inflorescence & 0.301 & -0.158 & 0.079 & 0.038 & 0.181 & 0.158 & $0.814^{\star}$ \\
\hline Peduncle fruit length & 0.341 & -0.001 & 0.198 & $0.749^{*}$ & 0.257 & -0.070 & 0.105 \\
\hline Weight fruit & $0.910^{*}$ & -0.195 & 0.019 & 0.186 & 0.044 & -0.036 & 0.171 \\
\hline Length fruit & $0.855^{*}$ & -0.210 & -0.045 & 0.219 & 0.037 & -0.007 & 0.180 \\
\hline Fruit diameter & $0.920^{*}$ & 0.075 & 0.078 & 0.142 & 0.055 & 0.116 & 0.167 \\
\hline Diameter of seminal cavity & $0.836^{*}$ & 0.109 & 0.198 & 0.098 & 0.107 & 0.118 & -0.082 \\
\hline Flesh density & -0.357 & 0.548 & 0.026 & -0.397 & -0.050 & -0.228 & 0.297 \\
\hline Length flower & -0.101 & -0.135 & 0.260 & 0.337 & 0.141 & $-0.777^{\star}$ & 0.052 \\
\hline Variance explained (\%) & 30.399 & 15.899 & 12.354 & 9.294 & 6.882 & 6.226 & 4.527 \\
\hline Eigenvalue & 5.471 & 2.861 & 2.223 & 1.672 & 1.238 & 1.120 & 0.814 \\
\hline
\end{tabular}


both males and females based on 17 accessions (table I) show that the sexual type affected most traits, as only internodes, plant height and stem diameter showed no appreciable effect of sexual type (table III). Correlation analysis on those accessions presenting both male and female plants display a significant relation $(r=0.74)$ between the length of the male inflorescence and the fruit size in the female.

In the data set constituting only female plants, high correlations are observed between fruit dimensions (weight, length, width and diameter of seminal cavity), with correlation indices between 0.78 and 0.92 , leaf length and width $(r=0.86)$, plant height and stem diameter $(r=0.72)$. Plant height and height at first fruit are less correlated $(r=0.68)$. Leaf and petiole lengths show a very moderate correlation of 0.44 . A small negative correlation is observed between internode length and number of nodes to first flower $(r=-0.40)$.

In the PCA, the first seven principal components take into account $86 \%$ of the total variance. The first one is related to fruit size, the second one to plant height and first fruit height, the third one to leaf and petiole size, the fourth to peduncle size, the fifth to the length and number of internodes to first flower, the sixth to the flower length/width ratio, and the seventh to the number of flowers of the inflorescence (table IV).

In the dendrogram obtained from the first seven components of quantitative variation, with a weak ten-branch structure, a small part seems to be of geographic origin, as indicated by branches 4 and 6, composed of Venezuelan accessions, and branch 9, representative of Barbados germplasm (figure 2). However, the other Venezuelan accessions and the accessions from other origins are scattered in the other branches of the dendrogram. Guadeloupe and Venezuela are the origins showing the widest variation in quantitative traits, which could be partly related to their better representation in the collection.

In the dendrogram obtained with the qualitative descriptors, the structure is weak too (figure 3). However, there are some indications of a geographic component. Thus, all

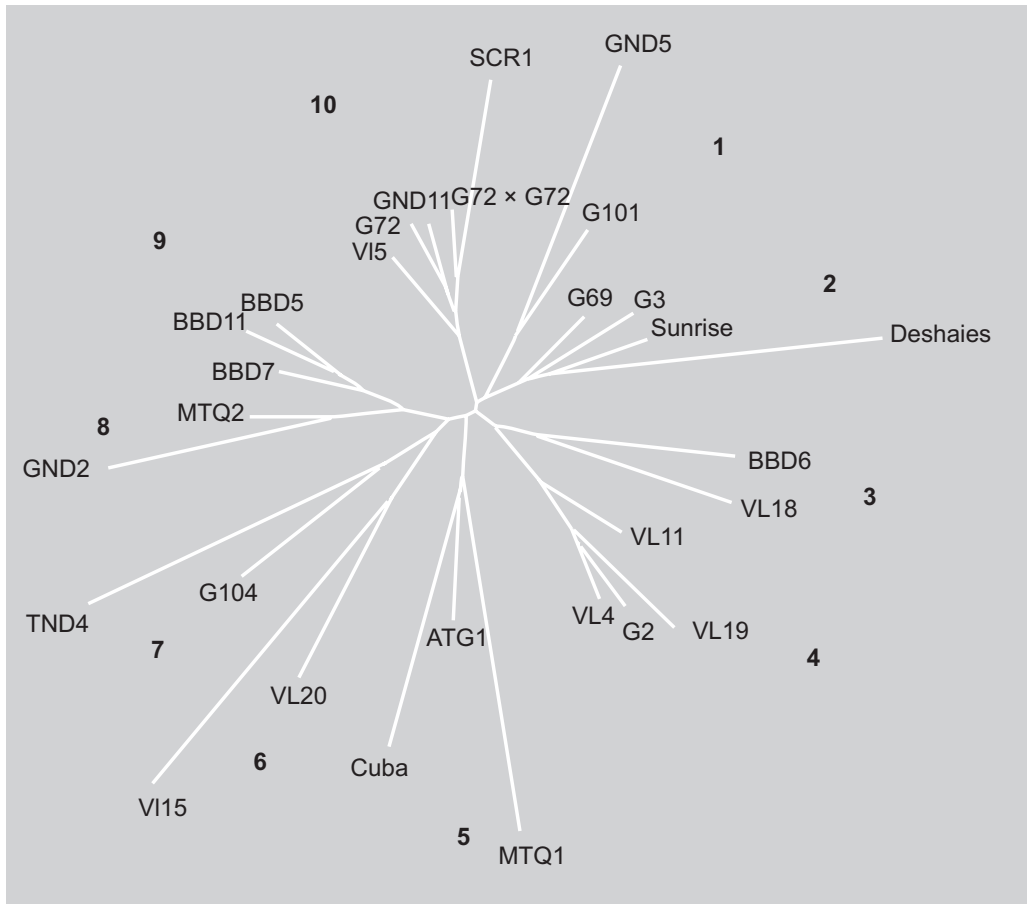

the Guadeloupean accessions but one are Figure 2.

concentrated in two branches ( 3 and 4) dis- Dendrogram from quantitative posed on one side of the tree. The two data obtained from Caribbean accessions from Martinique (branch 2) also and Venezuelan papaya appear uniform, forming a small cluster with germplasm individuals the one from Antigua. The Barbados acces- (Neighbor-Joining; Euclidian sions BBD 5, BBD 6 and BBD 11 tend to average distance). regroup, while BBD 7 shows more affinity with the Hawaiian Sunrise Solo. The Venezuelan accessions show the widest diversity, as they are scattered all over the dendrogram.

\subsection{Isozyme characterization}

All nine isozyme systems showed a good resolution; however, only ADH, PGM, PGI, SOD and PRX revealed polymorphism. SOD is dimeric, with two alleles and three electromorphs. The second allele predominates in most accessions. The first one is only present in accessions from Venezuela, Grenada and Guadeloupe. PGI is dimeric with two alleles and three electromorphs. The second allele predominates. It is absent in accessions from Hawaii (Solo and Sunrise Solo), Barbados (BBD 11), Costa Rica (CR 1), Guadeloupe (G3) and Venezuela (VL 17), 


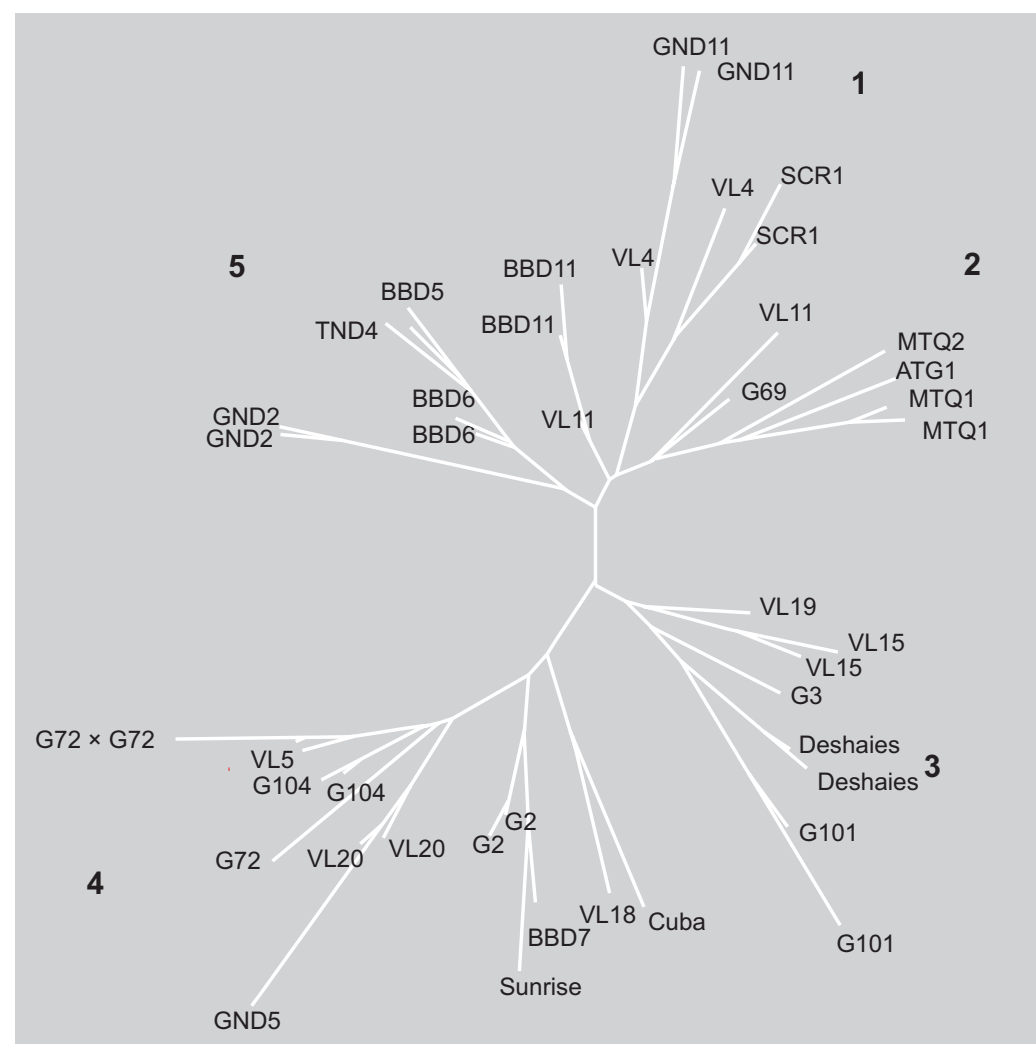

Figure 3.

Dendrogram from qualitative data obtained from Caribbean and Venezuelan papaya germplasm individuals (Neighbor-Joining; Sokal and Michener distances).

\section{Figure 4.}

Phenotypes observed for each isozyme system in Caribbean and Venezuelan papaya germplasm samples.

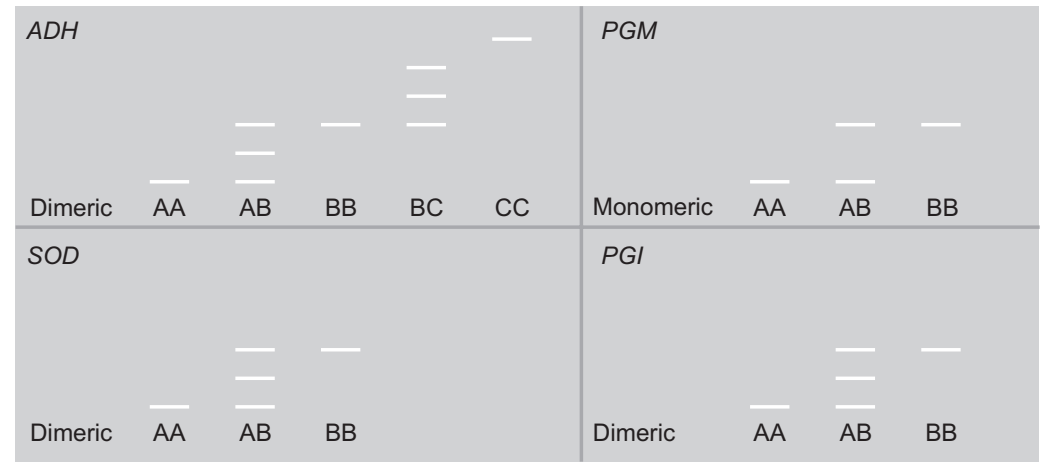

Possible phenotypes for each isozyme system could thus be proposed (figure 4). No particular association was observed between a given zymotype and sexual type.

Thirty-four zymotypes were identified on the 86 individuals, 31 of which appeared homozygous at the four selected loci. These belong mainly to the accessions from Hawaii (Solo and Sunrise Solo), Trinidad (TND 4), Costa Rica (CR 1), Cuba (CUBA), Barbados (BBD 11) and Venezuela (VL 19). The dendrogram obtained with NeighborJoining cluster analysis (figure 5) is divided into four branches showing a limited relation to a geographic structure. The accessions bearing the ADH third allele (Solo, Sunrise Solo, VL 20, VL 17, BBD 7 and BBD 11) are tightly grouped at the extremity of the first branch. The Venezuelan accessions once again are scattered all over the tree, except on the main subbranch of branch 4 . The Guadeloupean accessions are better grouped, as they are only present on branch 4 . The Barbados accessions are concentrated on branch 1, with two BBD 6 zymotypes on the neighboring branches 2 and 3.

The total diversity of the analyzed germplasm with the polymorphic loci was 0.42 with a major inter-individual component (0.30) and a relatively high level of heterozygosity (0.25). Despite this heterozygosity, the Fixation Index (Wright's F) was high (0.40)

The dendrogram (figure O), corresponding to the dissimilarity and genetic diversity matrix for the six best-represented populations (table $V$ ), is clearly divided into two main branches, each one representing three islands. Barbados is the most distant. However, its diversity is high (0.41), mainly due to the higher level of heterozygosity (0.42). Venezuelan accessions show high affinities with those of the islands. The germplasm from this country shows the highest total diversity (0.42) due to a high level of interindividual diversity (0.29), while heterozygosity is relatively low compared with other origins. The genetic distance between Venezuelan and Trinidadian germplasm is particularly low (0.04), which should be related to the fact that Trinidad is the island closest 
to Venezuela. Among the islands, Guadeloupean accessions show a high diversity and an intermediate affinity with those from other origins. Grenada and Martinique show the closest proximity (0.02) despite their low diversity (0.27 and 0.30). For three islands (Barbados, Trinidad and Martinique), the analysis supports the panmictic hypothesis, while there is a moderate deviation in Guadeloupe (0.23) and a high one in Venezuela and Grenada (0.40 and 0.36).

\section{Discussion}

The analysis of variance showed a marked influence of sex on the quantitative traits evaluated, except on those related to stem size (plant height, internode length and stem diameter). Our results thus confirm the results of Somsri [9], showing a difference in the height and number of nodes to first flower, and add floral traits and, more interestingly, leaf dimensions to the list of sexinfluenced traits. However, the divergence with the results of Nakasone and Storey [10], who found no such effect, requires carrying out further studies on other samples before drawing general conclusions. No association between zymotype and sexual type was found in our sample, such as those reported by Tan and Weinheimer [11] and Somsri [9].

Strong correlations were logically observed between traits related, respectively, to fruit dimensions, stem parameters and leaf size, defining the first three principal components of quantitative variation. The correlation between the length of the male inflorescence and fruit size is worth verifying in further studies.

The high morphological diversity observed in the collection does not correspond to a differentiation between island populations. The two dendrograms based on quantitative and qualitative traits showed a very limited geographic structuration of diversity. In both cases, the germplasm from Venezuela, and to a lesser extent from Guadeloupe, presented the highest variation, being scattered all over the tree, with little or no differentiation from most remaining accessions, while the accessions from Barbados tend to regroup in particular clusters.

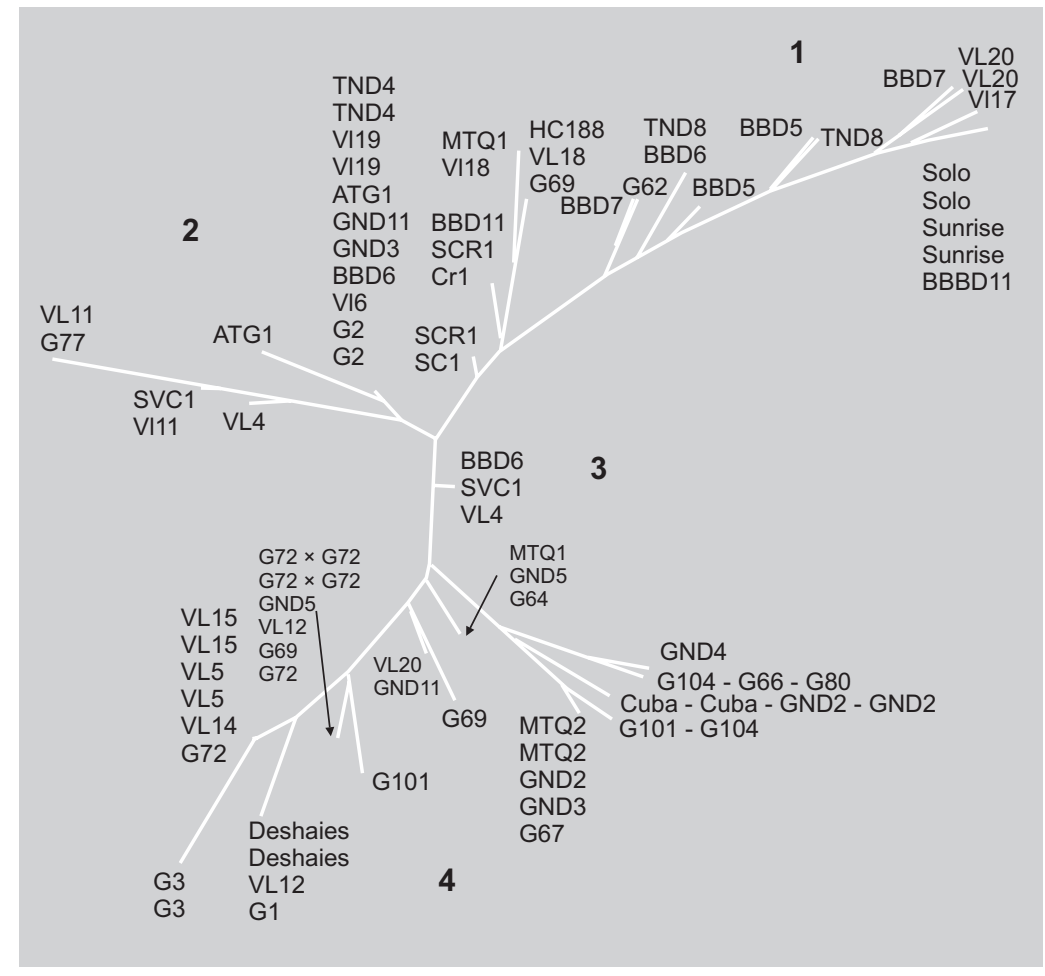

Figure 5.

The isozyme study showed that most Dendrogram showing the accessions are not fixed and still present a relationships among the 46 high level of heterozygosity, which can be accessions of Caribbean and related to the plant dioecy and to the low Venezuelan papaya level of selection in landraces of Venezuela germplasm, as obtained from and the West Indies. With four polymorphic isozyme data (Neighborisozyme systems out of the nine tested, our results are intermediate between those of Somsri [9] on a sample from Asia and the Pacific (5/15) and those of Morshidi [12] on an American sample (6/9). As in the latter, $\mathrm{MDH}$ and IDH appeared monomorphic; SKD, which showed three alleles in the American sample, appeared monomorphic in our sample; PGM and PGI, the two other systems that can be compared, are polymorphic in both cases; however, Morshidi [12] observed four alleles in PGI, while we observed only two. In the end, it seems that the diversity is, logically, slightly less in our East-Caribbean sample as compared with the wider American sample of Morshidi [12].

Most of the analyzed accessions are dioecious. That means that strict allogamy is the major mating system in our population. Thus, the relatively high level of the fixation Joining; Jaccard distance) 


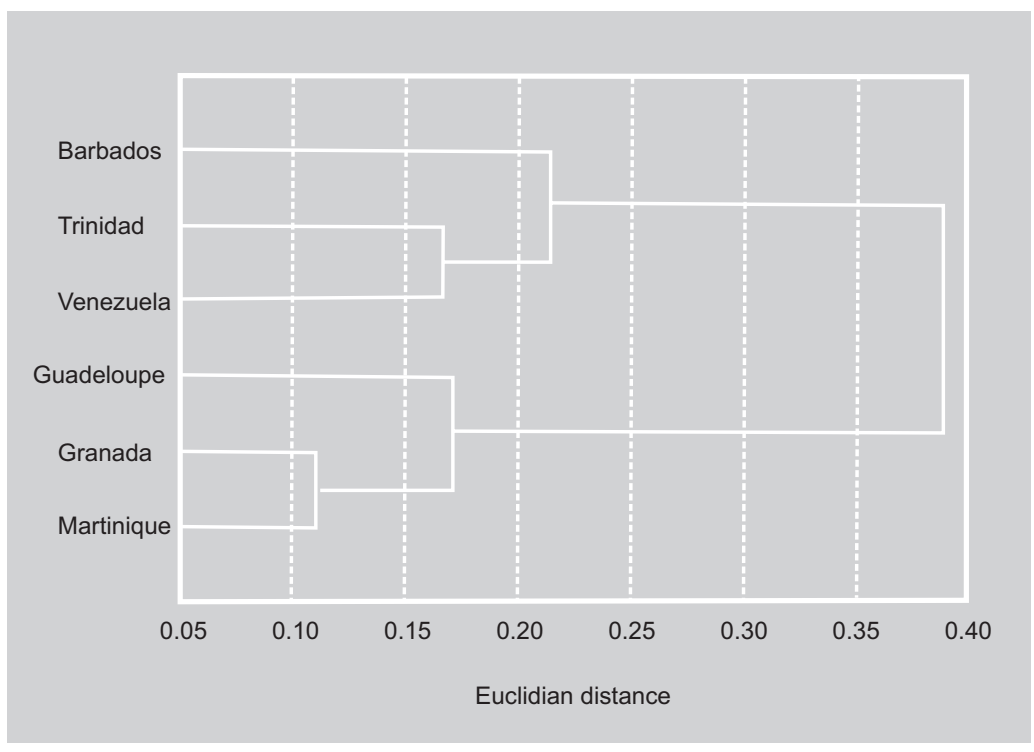

Figure 6.

Dendrogram based on genetic distances among populations of Caribbean and Venezuelan papaya as obtained from isosyme data (HAC; Euclidian distance). index (F) in the whole sample should be mostly associated with a subdivided population model with limited gene flow (Walhund effect). The archipelagic nature of the studied area is one component of this subdivision.

The cluster analysis based on the observed zymotypes shows a geographic structuration of diversity higher than those based on morphological traits, the accessions of Guadeloupe displaying a more limited dispersion. Those from Barbados tend to regroup in the loosest branch of the dendrogram. Their association with Solo and
Sunrise Solo seems logical regarding the Barbadian origin of the germplasm from which Solo was selected in Hawaii. Again, the accessions from Venezuela show the highest variation. The geographic structure is better evidenced when the accessions from the most common origins are grouped for a study of diversity within and between islands. Indeed, the corresponding dendrogram shows a divergence between Guadeloupe, Martinique and Grenada, i.e., three of those islands that are regularly spaced along the Arc antillais (Leeward and Windward Islands), on one side, and Venezuela and the neighboring island of Trinidad on the other side. In addition, this geographic diversity study confirms the diversity and relative divergence of the germplasm from Barbados, an island lying quite apart from the others and from the mainland.

However, it appears that islands such as Guadeloupe and Grenada, as well as Venezuela, display a significant deficit of heterozygotes ( $\mathrm{F}$ between 0.23 and 0.40 ). That could be explained by the very discontinuous nature of papaya populations, leading to endogamy in very small subpopulations. In turn, this subdivision can be related to the severity of the bacterial decline epidemics. Indeed, only isolated very small populations have a chance to escape the disease in these areas, a situation that contrasts with the widely scattered populations (cultivated plots, home gardens and subspontaneous individuals) that can be observed in most other tropical lowlands.

\section{Table V.}

Dissimilarity coefficients matrix and population genetic diversity among six populations (isozyme data) of papaya.

$\begin{array}{lcccccc}\text { Population } & \text { Barbados } & \text { Guadeloupe } & \text { Grenada } & \text { Martinique } & \text { Trinidad } & \text { Venezuela } \\ \text { Guadeloupe } & 0.24 & - & - & - & - & - \\ \text { Grenada } & 0.23 & 0.07 & - & - & - & - \\ \text { Martinique } & 0.26 & 0.07 & 0.02 & - & - & - \\ \text { Trinidad } & 0.05 & 0.18 & 0.13 & 0.21 & - & - \\ \text { Venezuela } & 0.08 & 0.07 & 0.11 & 0.17 & 0.04 & - \\ \text { Total diversity } & 0.41 & 0.38 & 0.27 & 0.30 & 0.32 & 0.42 \\ \text { Heterozygozity } & 0.42 & 0.28 & 0.18 & 0.38 & 0.31 & 0.25 \\ \text { F (Wright) } & 0.01 & 0.23 & 0.36 & -0.02 & 0.02 & 0.40 \\ \text { Inter-individual diversity } & 0.20 & 0.23 & 0.18 & 0.15 & 0.16 & 0.29\end{array}$


With only four out of nine systems displaying polymorphism, isozyme variation appeared lower than expected from the morphological observations. Studies with RAPD [23, 24] and AFLP [25] markers have shown poor genetic variation in the common papaya, not correlated with the magnitude of the morphological differences. The dendrogram drawn from AFLP data [25] also shows a very limited geographic structuration of the global papaya genetic diversity, with the formation of seven clusters, four of which correspond to germplasm from Central America, a region of relatively wider diversity, and two groups corresponding, respectively, to Australian openpollinated dioecious cultivars, adapted to subtropical conditions, and to Hawaiian inbred hermaphrodite cultivars and lines of the Solo type. Genetic diversity is the same within these two groups, so the differentiation of the Solo type material does not appear to be related to inbreeding during selection. Indeed, it could be attributed to the geographic origin of Solo, which is precisely Barbados, the island whose germplasm was most differentiated in our study.

\section{Conclusion}

Isozyme analysis shows that a relative isolation of the populations in the different islands has favored geographic differentiation. However, it appears limited, with very few isozyme alleles associated with particular regions and the absence of geographic differentiation for morphological characters. Genetic diversity in the whole sample is significantly lower than that observed in wider germplasm collections, while local populations maintain a significant level of heterozygosity.

The divergence of the germplasm from the more geographically isolated island of Barbados underlines the limited migration from other islands. Regarding the high quality of Barbadian papaya and its genetic differentiation, it appears particularly important to preserve Barbadian papaya germplasm. The diversity of accessions from Venezuela and Guadeloupe, together with the occurrence of resistance/tolerance to bacte- riosis, also gives them priority in planning germplasm conservation and evaluation.

The heterozygosity observed in most materials will pose a problem for conservation, unless efficient seed conservation procedures are developed. Endogamy in the collection may lead to genetic drift and erosion. On the other hand, endogamy will be necessary for any breeding effort aimed at proposing uniform cultivars to local growers.

The differentiation observed between the good-quality papayas form Barbados and the related cultivar Solo on one hand, and the populations from Guadeloupe, including resistant/tolerant genotypes, on the other hand, encourages the development of resistance markers to assist the selection of recombinants.

\section{References}

[1] Webb R.R., Epidemiology and control of bacterial canker of papaya caused by an Erwinia sp. on St. Croix US Virgin Islands, Plant Dis. 69 (4) (1985) 305-309.

[2] Gardan L., Christen R., Achouak W., Prior P., Erwinia papayae sp. Nov., a pathogen of papaya (Carica papaya), Int. J. Syst. Evol. Microbiol. 54 (2004) 107-113.

[3] Frossard P., Un dépérissement du papayer aux Antilles françaises associé à une Erwinia sp. du groupe amylovora, Fruits 40 (1985) 583-595.

[4] Prior P., Béramis M., Rousseau M.T., Le dépérissement bactérien du papayer aux Antilles françaises, Agronomie 5 (10) (1985) 877-885.

[5] De Lapeyre de Bellaire L., Lyannaz J.P., Evidence for resistance sources to bacteria canker in local Guadeloupe populations of Carica papaya, Trop. Fruit. Newsl. 3 (1992) 6-7.

[6] Manshardt R.M., Zee F.T.P., Papaya germplasm and breeding in Hawaii, Fruit Var. J. 48 (3) (1994) 146-152.

[7] Alvarez R., Gómez G., Martínez E., Mejoramiento genético de la papaya Carica papaya L. por ciclos de selección y recombinación en poblaciones avanzadas de híbridos varietales, in: V. Congreso Sociedad 
Colombiana de Fitomejoramiento y Producción de Cultivos: Memorias La sostenibilidad y la competitividad en el desarrollo de los cultivos, Santa Marta, Colombia, 1997, p 29.

[8] Sánchez E., Samaniego J.A., Comportamiento fenológico de variedades de papayo en el sur de Sonora, in: XVII Congreso de Fitogenética, Acapulco, Mexico, 1998.

[9] Somsri S., Improvement of papaya (Carica papaya L.) for South-East Queensland: investigation of sex-type and fruit quality, Aust. New Crop. Newsl. 11 (25.2) (1999).

[10] Nakasone H.Y., Storey W.B., Studies on the inheritance of fruiting height of Carica papaya L., Am. Soc. Hortic. Sci. Proc., 66, 1955, pp. 168-182.

[11] Tan S.C., Weinheimer E.A., The isoenzyme patterns of developing fruit and leaf of papaya (Carica papaya L.), Sains Malays. 5 (1976) 7-14.

[12] Morshidi M., Genetic control of isozymes in Carica papaya L., Euphytica 103 (1) (1998) 89-94.

[13] Morshidi M., Manshardt R.M., Zee F., Isozyme variability in wild and cultivated Carica papaya, HortScience 30 (1995) 809.

[14] Jobin-Decor M. P., Graham G.C., Henry R.J., Drew R.A., RAPD and isozyme analysis of genetic relationships between Carica papaya and wild relatives, Gen. Res. Crop Evol. 44 (5) (1997) 471-477.

[15] Manshardt R.M., Wenslaff T.F., Zygotic polyembryony in interspecific hybrids of Carica papaya and C. cauliflora, J. Am. Soc. Hortic. Sci. 114 (4) (1989) 684-689.

[16] Moore G.A., Litz R.E., Biochemical markers for Carica papaya, C. cauliflora, and plants from somatic embryos of their hybrid, J. Am. Soc. Hortic. Sci. 109 (2) (1984) 213-218.
[17] Manshardt R.M., Wenslaff T.F., Interspecific hybridation of papaya with other Carica species, J. Am. Soc. Hortic. Sci. 114 (4) (1989) 689-694.

[18] Chen M.H., Wang C.C., Wang D.N., Chen F.C., Somatic embryogenesis and plant regeneration from immature embryos of Carica papaya $\times$ C. cauliflora L. cultured in vitro, Can. J. Bot. 69 (9) (1991) 1913-1918.

[19] Anon., Descriptors-for-papaya, IBPGR, FAO, Rome, Italy, 1988.

[20] Saitou N., Nei M., The neighbor-joining method: a new method for reconstructing phylogenetic trees, Mol. Biol. Evol. 4 (1987) 406-425.

[21] Wright S., The interpretation of population structure by $F$-statistics with special regard to system of mating, Evolution 13 (1965) 395-420.

[22] Nei M., Analysis of gene diversity in subdivided population, Proc. Natl. Acad. Sci. US 70 (1973) 3321-3323.

[23] Sondur N.S., Manshardt R.M., Stliles J.I., A genetic linkage map of papaya based on randomly amplified polymorphic DNA markers, Theor. Appl. Genet. 93 (4) (1996) 547553.

[24] Stiles J.I., Lemme C., Sondur S., Morshidi M.B., Manshardt R.M., Using randomly amplified polymorphic DNA for evaluating genetic relationships among papaya cultivars, Theor. Appl. Genet. vol. 85 (6-7) (1993) 697-701.

[25] Kim M.S., Moore P.H., Zee F., Fitch M.M.M., Steiger D.L., Manshardt R.M., Paull R.E., Drew R.A., Sekioka T., Ming R., Genetic diversity of Carica papaya as revealed by AFLP markers, Genome 45 (3) (2002) 503512. 


\section{Organización de la diversidad morfológica y genética del germoplasma de papaya en el Caribe y Venezuela.}

Resumen - Introducción. El impacto de la bacteriosis, que impide el desarrollo de la papaya en las Antillas, ha incitado a la creación de un programa destinado a transferir los factores de resistencia genética de genotipos locales hacia cultivares comerciales. En una primera etapa, una colección de germoplasma caribeño ha sido constituida para estudiar la diversidad morfológica y genética. Materiales y métodos. La muestra total incluye 50 accesiones provenientes de las Pequeñas Antillas, Cuba, Venezuela, Costa Rica y Hawai. Los datos morfológicos de una submuestra de 29 accesiones han sido sometidos al análisis de varianza, componentes principales, y a una clasificación por el método de Neighbor Joining. Nueve sistemas enzimáticos han sido evaluados y los datos generados han sido tratados por análisis de clasificación y parámetros genéticos, incluyendo índices de fijación, diversidad y heterocigocidad. Resultados. Dieciocho de las 47 accesiones del Caribe y Venezuela presentaron plantas hermafroditas. Las accesiones de Venezuela han mostrado la mayor diversidad morfológica, mientras que las de Barbados se han distinguido por la calidad del fruto. El tipo sexual ha influenciado sobre los caracteres foliares y florales. La clasificación muestra poca diferenciación morfológica entre orígenes, con un relativo agrupamiento de las accesiones de Guadalupe y Barbados. Sólo cuatro sistemas enzimáticos han revelado polimorfismo, generando 34 zimotipos, con un heterocigocidad relativamente elevada y una diversidad particular en Venezuela, Guadalupe y Barbados. La estructuración geográfica aparece limitada en el análisis entre individuos, pero es más clara cuando se consideran las seis poblaciones mejor representadas, con la agrupación de las accesiones de Venezuela, Trinidad y Barbados, y la de Guadalupe, Martinica, y Granada. Discusión. El bajo nivel de fijación puede ser atribuido a la dioecia y al bajo nivel de selección. El relativo aislamiento de las poblaciones insulares ha contribuido a una diferenciación geográfica limitada. La divergencia entre el germoplasma de buena calidad de Barbados y las poblaciones tolerantes de Martinica y Guadalupe es favorable al desarrollo de un esquema de mejoramiento genético asistido por marcadores.

Caribe / Venezuela / Carica papaya / germoplasma / isoenzimas 